\title{
Faktaa, fiktiota ja feikkiuutisia - miten olla hukkumatta informaatiotulvaan?
}

\author{
Maria Lassila-Merisalo
}

$\mathrm{Mi}$ inut kutsuttiin puhujaksi informaatiolukutaidon seminaariin päivälleen tasan puoli vuotta ennen seminaaria. Hahmottelin silloin esitykselleni otsikon Faktaa, fiktiota ja feikkiuutisia - miten olla hukkumatta informaatiotulvaan? Kuin tilauksesta kaksi päivää ennen seminaaria julkaistiin tutkimus, jonka mukaan jopa puolet suomalaisista uskoo ammattimaisen median tekevän valheellisia uutisia (Virranta 2017). Tulos oli tutkimuksen tekijän mukaan hämmästyttävä. Jotakin merkittävää on tosiaan tekeillä, ja puheeni aihe on nyt ajankohtaistakin ajankohtaisempi.

Käännetään katse hetkeksi menneisyyteen ja median kehitykseen. Toistasataa vuotta sitten journalismi oli sivutoiminen työ. Esimerkiksi Eino Leino ja Juhani Aho rahoittivat kaunokirjallista toimintaansa lehtikirjoittelulla. Tuohon aikaan uutinen ei alkanut tapahtuman ytimellä. Uutinen pehtoori Stylmanin automobiilionnettomuudesta alkoi pehtoorin aamuisesta heräämisestä ja eteni kronologisesti kohti varsinaista uutisen arvoista tapahtumaa.

Toisen maailmansodan jälkeen journalismi professionalisoitui vauhdikkaasti. Toimittajista tuli päätoimisia ammattilaisia. Uutisella harjaannuttiin vastaamaan kysymyksiin mitä, missä, milloin, miksi ja miten; tärkein edellä. Tämä tapahtui luonnontieteellisen paradigman valta-aikana, ja journalismin ihanteeksi muodostui objektiivisuus; ajatus siitä, että todellisuudesta an sich on saatavilla puhdasta tietoa. Ihanteen saavuttaminen ei kuitenkaan ollut helppoa, ja toimituksissa syntyi erilaisia keinoja tuottaa objektiiviselta vaikuttavaa sisältöä. Yksi niistä on Tuchmanin objektiivisuuden strateginen rituaali (1972), jota toteutetaan mediassa tänäkin päivänä. Esimerkiksi käy kuvitteellinen ilmastonmuutosta käsittele- vä lehtijuttu. Oletetaan, että 95 prosenttia tutkijoista on sitä mieltä, että ilmastonmuutos on todellinen ja ihmisen aiheuttama ilmiö. Vain viisi prosenttia tutkijoista kyseenalaistaa tämän ja väittää asian olevan toisin. Koska journalistin tehtävänä on olla tasapuolinen, lopullisessa jutussa nämä vastakkaiset näkemykset saattavat saada yhtä paljon palstatilaa. Näin lukijalle syntyy virheellinen mielikuva tasavahvasti kamppailevista näkemyksistä.

Pääsin 2000-luvun alussa nuorena tutkijana toimittajien tärkeään tapahtumaan, Journalismin päivään, puhumaan faktan ja fiktion ja objektiivisuuden ja subjektiivisuuden välisistä suhteista. Esitin salilliselle toimittajia varovaisen ajatuksen: entä jos avoimesti subjektiivisella jutulla voisikin olla mahdollista saavuttaa maailmasta jopa totuudellisempi kuva kuin perinteisen objektiivisuuden keinoin? Ajatukseni ei herättänyt vastakaikua, päin vastoin.

Viime vuonna olin Mediatutkimuksen päivillä. Käynnissä oli ammattitoimittajien paneelikeskustelu. Helsingin Sanomien Jussi Pullinen esitti pohdintansa: tuskin kukaan toimittaja enää uskoo siihen, että journalistinen objektiivisuus olisi mahdollista. Aika oli nyt kypsä. 1970-luvun luonnontieteellisessä eetoksessa koulutetut toimittajat eivät olleet vuosituhannen vaihteessa valmiita luopumaan ideaaleistaan - riippumatta siitä, oliko niitä koskaan edes todella saavutettu. 1970-luvulla syntyneet toimittajat sen sijaan näkevät todellisuuden nyt jo toisin silmin: erilaisina kontekstisidonnaisina tulkintoina. Tämä ei sulje pois totuuden tavoittelun päämäärää.

Tällä vuosituhannella mediakentällä on tapahtunut todella paljon. Perinteinen media sai ison kolhun tiedonvälittäjän rooliinsa tapaninpäivä- 
2. Kuinka luotettava tekstin julkaisuympäristö on?

Tarkastele, onko teksti julkaistu tieteellisessä julkaisussa vai esimerkiksi henkilökohtaisessa blogissa? Onko julkaisijalla kaupallisia, poliittisia tai muita intressejä, jotka voisivat vaikuttaa tekstin luotettavuuteen?

$\triangle$ hyvin luotettava

$\square$ melko luotettava

$\square$ ei kovin luotettava

\section{Perustele vastauksesi lyhyesti.}

Teksti on tunnetulta kaupalliselta sivustolta. Se on puutarhamyymälän oma sivusto, johon on koottu vinkkejä kesäkukkien kasvatuksesta ammattilaisten (työntekijöiden) avulla.

Kuva 1. Opiskelijan arvio tietolähteen luotettavuudesta.

vauvojen keskinäinen charmi saa meidät varmasti hymyilemään.

On hyvin ymmärrettävää, että ihmisillä on kaipuu nähdä ja kuulla hellyttäviä ja positiivisia asioita. Maailma on epävakaa, ja mediassa negatiiviset sisällöt korostuvat. Toimituspäällikön lausunnosta tekee kuitenkin huolestuttavan se, että Arvostettu.com ei ole journalistinen media. Jos journalistinen media asettuu sen kilpailijaksi, se luopuu omasta journalistisesta integriteetistään

nä 2004, kun Intian valtamerellä nousi tsunami. Suomalaiset sukellusyrittäjät päivittivät Thaimaassa verkkosivuilleen tietoja suomalaisturistien kohtaloista nopeammin kuin minkään median mekanismi pystyi toimimaan.

Väitän silti, että yksi yksittäinen tekijä nousee yli muiden: Facebook. Miksi Facebook on ollut mediankin kannalta niin merkittävä? Monesta syystä. Ensinnäkin, yleisö oli ollut medialle siihen asti mysteeri. Lukijatutkimuksia oli toki teetetty, mutta niiden luotettavuus tiedettiin ongelmalliseksi; haastattelutilanteessa moni ihminen kaunistelee hiukan todellisuutta ja kertoo lukeneensa uutisia Seiskan sijaan. Facebookin myötä saatiin käyttäjien tykkäyksiä ja jakoja seuraamalla suoraa tietoa siitä, mitä yleisö haluaa: kissavideoita, sankaritarinoita suloisien vauvojen ja eläinten pelastajista, pehmeitä ja positiivisia tarinoita kiireisen arjen ja negatiivisten uutisten vastapainoksi.

Ja heti perään tuli taantuma. Media-alan alamäki kiihtyi. Taloudellisessa kurimuksessa media halusi entistä kiivaammin miellyttää yleisöä pitääkseen kiinni tilauksistaan. Erään suuren suomalaisen mediatalon toimituspäällikkö kertoi pari vuotta sitten minulle, että heidän tärkein kilpailijansa on Arvostettu.com, käännössivusto, joka tarjoaa käyttäjälle valmiiksi pureskel tuja tunnereaktioita. Sivustolla päätetään puolestamme, mikä kahdeksasta vauvasta on söpöin tai että kaksos- ja alkaa pelata uutta peliä, uusilla säännöillä.

Toinen iso muutos, jonka Facebook ja muut sosiaalisen median palvelut ovat tuoneet, on julkaisukanavan merkityksen sumeneminen. Suurin osa meistä tunnistaa ilmiön: luimme jutun, joka oli jaettu Facebookiin, mutta emme muista, mikä sen alkuperäinen julkaisukanava oli. Tämä antaa tasoitusta erikois- ja vaihtoehtomedioille. Ne voivat saada tilaa julkisessa keskustelussa ja ihmisten maailmankuvan rakentamisessa yhtä lailla kuin vanhat valtamediat.

Vaikka median murros on totta ja suuri asia, ei media ole koskaan ollutkaan mitään staattista ja pysyvää, vaan kehittyvä ja muuttuva olio. Mahtuvatko viime vuosien muutokset kuitenkaan normaalin vaihtelun sisään?

Viime aikoina julkisuudessa ovat nousseet esiin kaiken maailman dosentit ja vaihtoehtoiset faktat. On puhuttu totuuden ja vielä kuvaavammin luottamuksen jälkeisestä ajasta. Alussa mainitsemassani tutkimuksessa selvisi, että erikoissivustojen kuten MV-lehden sekä poliittisten, aatteellisten ja ideologisten sivustojen uskotaan tuottavan eniten valheellisia sisältöjä. Mutta toisaalta: MVlehden lukijat uskovat vahvimmin tunnistavansa valeuutisen. (Herranen 2017.) Yhtenäiskulttuurin aika on totisesti ohi: me jakaudumme. Luottamus instituutioihin rapautuu, asiantuntijuus määritellään uudelleen.

Vaihtoehtoiset totuudet kilpailevat keskenään. 


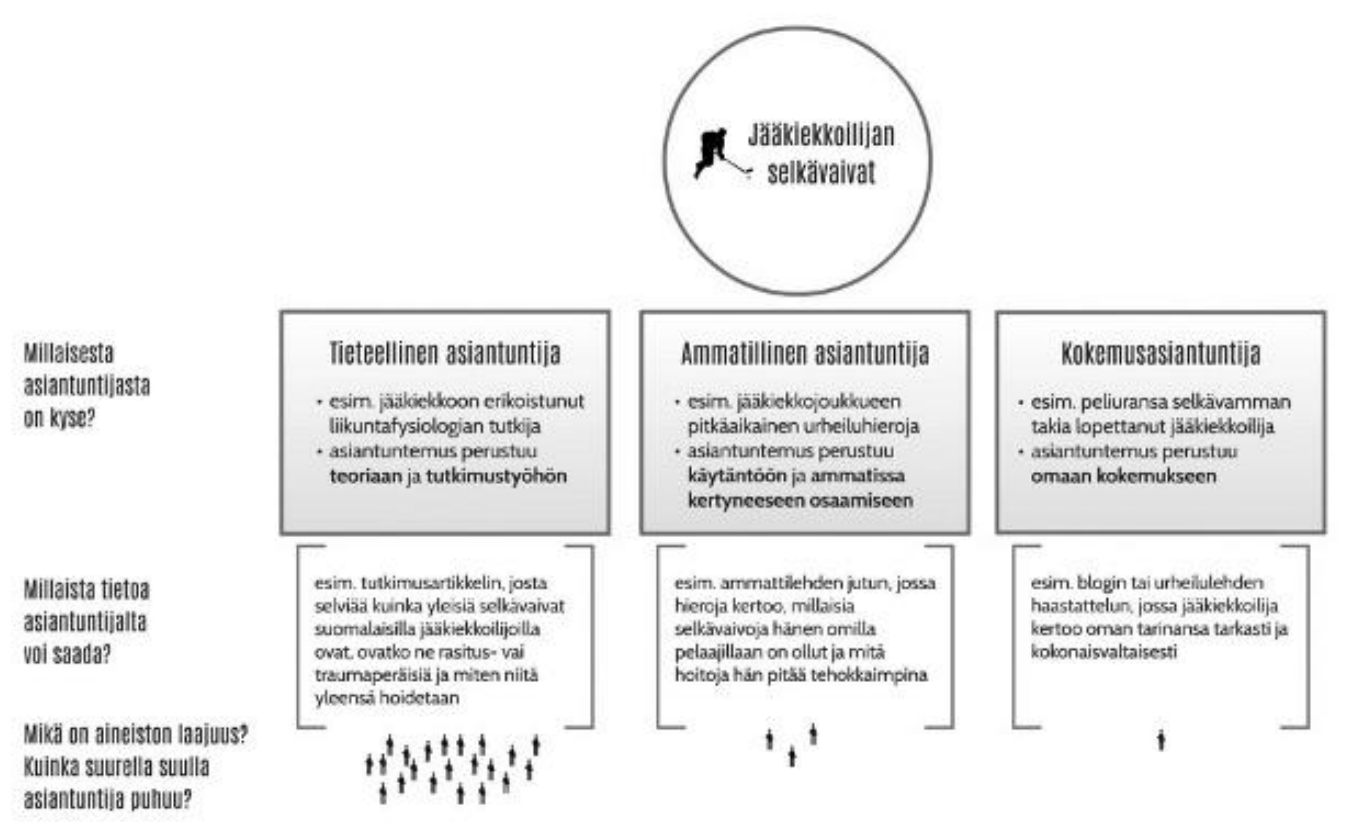

Kuva 2. Tietolähteen luotettavuus (Lassila-Merisalo 2016).

Yksi ei usko mitään, mitä lukee ja näkee, toinen taas uskoo kritiikittä kaiken. Miten tämän kaiken keskellä voi opettaa informaatiolukutaitoa? Kuvassa 1 on kuvakaappaus vastauksesta, joka on poimittu Hämeen ammattikorkeakoulun Tiedonhausta tekstiksi -kurssilta, jolla yhtenä tehtävänä oli aiemmin valitun tiedonlähteen arviointi.

Arviointilomake ohjasi lähdekritiikkiin; kuten näkyy, kysymyksessä neuvotaan etsimään erilaisia intressejä, joilla voisi olla vaikutusta lähteen luotettavuuteen. Opiskelija tunnistaa lähteensä kaupallisuuden, mutta arvioi siitä huolimatta lähteen hyvin luotettavaksi. Ei ole mikään ihme, että opiskelijat ovat hämillään. Sisältömarkkinointi ja natiivimainonta sumentavat nykyään tehokkaasti sisältöjen välisiä rajoja, kun sanomatai aikakauslehden sisällä on lehtijuttujen näköisiä maksettuja mainoksia. Verkkokaupan printtiesitekin voi näyttää enemmän aikakauslehdeltä kuin perinteiseltä mainoskatalogilta, ja vaatefirman uutiskirjeessä on asiantuntija-artikkeli, jota lukiessamme saatamme unohtaa, että uutiskirjeen lopullisena tavoitteena on saada meidät ostamaan firman vaatteita.

Asiantuntijuuden määritelmän laajeneminen ei ole yksinomaan huono asia. Olen esimerkiksi saanut tutkijanurani varrella joskus refereelausunnossa kritiikkiä artikkelistani, koska se on ollut liian helppolukuinen. Luettavuus ja ymmärrettävyys ovat olleet minulle tärkeitä arvoja, mutta on myös tieteilijöitä, jotka haluavat julkaista tutkimusta eksklusiivisella tieteen salakielellä. Sellaisen asiantuntijuuden kyseenalaistaminen voi tuottaa tervehdyttäviä tuloksia: tutkijat haastetaan kommunikoimaan ymmärrettävästi sen sijaan, että he piiloutuisivat käsitteidensä taakse.

Olen myös aina ollut sitä mieltä, ettei esimerkiksi opinnäytetyön tekijän tarvitse rajata lähteikseen ainoastaan tieteellisiä julkaisuja. Aiheen ajankohtaisuutta ja tärkeyttä voi hyvin perustella esimerkiksi julkisen somekeskustelun avulla. Kaikenlaiset lähteet ovat mahdollisia ja käytettävissä. Olennaista on se, minkä arvon niille antaa. Millaisesta asiantuntijuudesta on kyse?

Tein vuonna 2016 Hämeen ammattikorkeakoulun kirjaston verkkosivuille kuvan, jolla pyrin havainnollistamaan asiantuntijuuden painoa (kuva 2). Sen sijaan, että esimerkiksi kieltäisimme kategorisesti tiettyjen lähteiden käytön, voisimme painottaa lähteiden arviointia ja kontekstointia. 
Kuva esittää ideaalitilannetta, jossa kaikki lähteet ovat totuudellisia ja sikäli arvokkaita omassa lajissaan. Kuvioon tulee uusi taso, kun otetaan huomioon vaikkapa tieteelliset saalistajajulkaisut. Erityisesti yliopistojen puolella julkaisemisen merkitys on valtava. Tutkijoilla on kovat paineet julkaista, ja saalistajajulkaisijoiden yhä sofistikoituneemmat menetelmät voivat johtaa kokeneemmankin tutkjian harhaan. Tieteellistä artikkeliakin tulee siis tarkastella kriittisesti omassa kontekstissaan: onko se todella sitä, mitä se väittää olevansa?

Kirjoitin keväällä 2006 kolumnin, joka käsitteli televisiota ja ennen muuta tosi-tv:tä eräänlaisen pseudotodellisuuden luojana. Totesin silloin, että kodeissa on kasvava joukko kyynisiä ihmisiä, jotka eivät ota mediaa todesta. Virke pääsi Suomen Kuvalehden jyviin ja akanoihin, mutta on näin jälkikäteen katsoen hämmentävän totuudenmukainen. Tämä oli siis ennen Facebookia ja jytkyjä.

Nyt tuo fraasi on arkipäivää ja näkyy somessa joka päivä. Meidän todellisuutemme eivät ole samoja. Nuori sukupolvi kasvaa tähän maailmaan ja tulee opiskelemaan yliopistoihin ja ammattikorkeakouluihin, ja teidän pitäisi opettaa heille informaatiolukutaitoa.

Tieteellisten julkaisujen määrän on sanottu kaksinkertaistuvan yhdeksän vuoden välein (Ilén 2017). Kaiken kaikkiaan tiedon määrän arvioidaan kasvavan 23 prosenttia vuosittain (Hilbert \& López 2011). Miten informaatiotulvasta selviää hukkumatta? Mitkä ovat informaatiolukutaidon kriittisimmät osa-alueet tänä päivänä? Ja miten niitä tulisi opettaa? Nostan lopuksi esiin kolme asiaa, joiden merkitystä olen viime aikoina pohtinut.

1. Informaatiolukutaito on lopultakin melko yksinkertaista ja maalaisjärkistä, mutta sen käytäntöön soveltaminen edellyttää tiettyä tietopohjaa: tekstien lajityyppien ja julkaisukanavien perustuntemusta, median toimintaperiaatteiden ymmärrystä. Näiden asioiden tulee kulkea mukana myös substanssiopetuksessa. Informaatiolukutaito on me- tataito, joka leikkaa läpi ihmisen koko kulttuurisen ja yhteiskunnallisen toimintakompetenssin, ja jota ei voi ulkoistaa kirjastojen hoidettavaksi.

2. Julkisen keskustelun areena on avautunut, eikä sitä saa vedettyä enää takaisin vain tiettyjen autoritääristen tahojen hallintaan. Eteemme tulee faktaa ja fiktiota, totta ja valheita, erilaisia agendoja ja päämääriä. Terve epäily on rakentavaa, totuutta etsivää ja avointa. Terve epäilijä ei ole lukinnut omaa näkökantaansa etukäteen eikä hae tietoa vain pönkittääkseen omia aiempia näkemyksiään.

3. Jos haluamme lähentää eri todellisuuksista tulevia ihmisiä toisiinsa, teksti ei taida olla siihen tehokkain tapa. Tiedämme, miten helposti sähköpostiviestintä epäonnistuu; se johtaa väärinymmärryksiin ja konflikteihin, jotka useimmiten aukeavat, kun istutaan saman pöydän ääreen. Näemme, millaisia törkeyksiä ihmiset kirjoittavat sosiaalisessa mediassa.

Kun samanmieliset kerääntyvät yhteen ja puhaltavat ympärilleen kuplan, se voi olla hyvin vahva, jopa murtamaton oma todellisuutensa. Näitä on ollut aina, katsotaanpa vaikka äärimmäisiä uskonlahkoja ja sitä, kuinka vahvasti ne pitävät jäsenet hallinnassaan. Koko maailma tuskin pilkkoutuu ääriliikkeiksi, mutta suunta näyttäisi olevan lisääntyvä.

Ihmisen rooli informaation tuottamisessa on ainakin toistaiseksi merkittävä. Ehkä informaatiolukutaidon ytimessä onkin siis ihmisenlukutaito? Voimme ohjata opiskelijat analysoimaan yksinään erilaisia tekstejä, tunnistamaan eri lähdetyyppejä, arvioimaan niiden uskottavuutta ja niin edelleen, mutta lisääkö se opiskelijan ymmärrystä, jos hän pysyy koko ajan omassa kuplassaan?

Verkko-opiskelu on muodissa ja korkeakoulut mainostavat innolla kokonaan verkossa suoritettavia tutkintoja. Olen siis epätrendikäs ja vastavirrassa, kun esitän, että informaatiolukutaidon opetuksen pitäisi olla kontakti- ja ryhmäope- 
tusta. Taustalla voivat olla tietokannat ja Boolen operaattorit, mutta ehkä informaatiolukutaidon opetuksen kovin ydin kääntyykin siihen, että kirjastoalan ammattilaiset saavat opiskelijat kohtaamaan toisensa ja ymmärtämään toistensa todellisuuksia.

\section{Lähteet:}

Herranen, Tanja (2017). Valeuutistutkimus 14.11.2017. Medialiitto. Haettu 8.12.2017 osoitteesta http://www. medialiitto.fi/files/4323/Valeuutistutkimus_14.11.2017. pdf

Hilbert, Martin \& López, Priscilla (2011). The World's Technological Capacity to Store, Communicate, and Compute Information. Science 10.2.2011. Haettu 8.12.2017 osoitteesta DOI: $10.1126 /$ science. 1200970

Ilén, Ismo (2017). Tieteellisen tiedon määrä kaksinkertaistuu joka yhdeksäs vuosi. Blogipostaus. Hypermedia 9.2.2017. Haettu 8.12.2017 osoitteesta https:// hypermedia.fi/innoyritys/2017/02/tieteellisen-tiedonmaara.html
Lassila-Merisalo Maria (2016). Lähteen asiantuntijuuden arviointi. Hämeen ammattikorkeakoulu. Haettu 8.12.2017 osoitteesta http://www.hamk.fi/ kirjasto/tiedonhaku/miksi/Documents/jaakiekkoilijaesimerkki-iso.pdf

Tuchman, Gaye (1972). Objectivity as Strategic Ritual: An Examination of Newsmen's Notions of Objectivity. American Journal of Sociology 77(4): 660-679.

Virranta, Riikka (2017). Tutkimus: Jopa puolet suomalaisista uskoo ammattimaisen median tekevän valheellisia uutisia. Suomen Lehdistö 15.11.2017. Haettu 8.12.2017 osoitteesta http://www.suomenlehdisto. fi/tutkimus-jopa-puolet-suomalaisista-uskooammattimaisen-median-tekevan-valheellisia-uutisia/

\section{Tietoa kirjoittajasta:}

Maria Lassila-Merisalo, FT, dosentti

Strategisen viestinnän päällikkö,

Hämeen ammattikorkeakoulu

maria.lassila-merisalo@hamk.fi 